This item was submitted to Loughborough's Research Repository by the author.

Items in Figshare are protected by copyright, with all rights reserved, unless otherwise indicated.

\title{
The miller and his seigneur
}

\section{PLEASE CITE THE PUBLISHED VERSION}

https://doi.org/10.1386/btwo.7.2.203_7

\section{PUBLISHER}

(c) Intellect

\section{VERSION}

AM (Accepted Manuscript)

\section{PUBLISHER STATEMENT}

This work is made available according to the conditions of the Creative Commons Attribution-NonCommercialNoDerivatives 4.0 International (CC BY-NC-ND 4.0) licence. Full details of this licence are available at: https://creativecommons.org/licenses/by-nc-nd/4.0/

\section{LICENCE}

CC BY-NC-ND 4.0

\section{REPOSITORY RECORD}

Wilson, Michael. 2017. "The Miller and His Seigneur". figshare. https://hdl.handle.net/2134/32130. 


\section{The Miller and his Seigneur}

'Le meunier et son seigneur' (1995: 91-105)

Luzel published this story bilingually (in both French and Breton) in Contes Bretons remarking that his French version was a 'literal translation' from the original Breton. He also sub-titled the story 'an amusing tale' and it is the case that the humorous outcomes to the various episodes in which the miller gets the better of the seigneur, provide the main narrative impetus. Luzel also published the story in the third volume of Contes populaires de Basse-Bretagne (1887) along with a group of six other 'facetious tales'.

For those with an interest in comparisons, the story is a particularly fine variant of ATU1535 ('The Rich and the Poor Farmer'), which Hans-Jörg Uther traces back to the tenth century (2011: 268). Katherine Briggs includes a summary of 'Sheep for the Asking', a version collected from Kendal in The Lake District in 1914 (1970: 262-63) and she relates this to ATU1737 ('The Clergyman in the Sack to Heaven') which appears in Grimm as 'Big Klaus and Little Klaus'.

The humour, of course, derives from the besting of the socially superior and wealthy, but gullible seigneur by the socially inferior and poor, but wily miller and is consistent with Luzel's observation that Breton folktales almost invariably take the side of the poor against the wealthy and powerful. It is interesting that in the Breton context the story does not revolve around a poor brother and a rich brother, as is often the case in this story, but it is transformed into a criticism of, and triumph over, the much-hated seigneurial system, a form of land tenure based upon feudalism, common in eighteenth century France. It is a sentiment not uncommon in folktales, as explained by Jack Zipes:

He who has power can exercise his will, right wrongs, become ennobled, amass money and land, win women as prizes. This is why the people (das Volk) were the carriers of the tales: the Märchen catered for their aspirations and allowed them to believe that anyone could become a knight in shining 
armour or a lovely princess, and they also presented the stark realities of power politics without disguising the violence and brutality of everyday life. (1992: 29)

One further point of interest is how the story is begun by Barba Tassel, arguably Luzel's most prolific storyteller, a beggarwoman from Plouaret, who was also responsible for the delivery of the mail to the village. Rather than the more usual formulaic and formal beginning, this is a more conversational opening in which she begins the tale as if it is a continuation of a previous conversation.

\section{References}

Briggs, Katherine (1970) A Dictionary of British Folk-Tales: Part A, Folk Narratives, Vol.2, Bloomington: Indiana University Press

Luzel, François-Marie (1887) Contes populaires de Basse-Bretagne (in 3 volumes), Paris: Maisonneuve et Charles Leclerc

Luzel, François-Marie (1995) Contes Bretons, Rennes: Presses Universitaires de Rennes, Terre de Brume

Uther, Hans-Jörg (2011) The Types of International Folktales: A Classification and Bibliography, Part II, Tales of the Stupid Ogre, Anecdotes and Jokes, and Formula Tales (Second Printing), Helsinki: Folklore Fellows Communications

Zipes, Jack (1992) Breaking the Magic Spell: Radical Theories of Folk and Fairy Tales, New York: Routledge 
It had been four years since he had paid any rent* to the seigneur. That's how poor he was! One day the seigneur was on his way home from hunting and was in a bad mood because he hadn't caught a single thing and so, finding the miller's cow blocking the road, he shot and killed it. The miller's wife saw what happened and she ran up to the house, crying in dismay, "Alas! Alas! Now we are really done for! Our cow has been killed by the seigneur!"

The miller said nothing, but he was furious nonetheless. During the night he skinned the cow and he set off to sell the hide at Guingamp. Because it was a long way away and he wanted to reach the town by the early morning, he left the house around midnight. As he walked through the wood, where according to rumour there lived a band of fearsome robbers, he became frightened and he climbed up a tree and waited for the morning.

Soon a band of robbers arrived at the tree to divide up their money. And there was so much squabbling and noise, they just couldn't agree on anything.

"Jesus, if only I could have that money!" said the miller to himself. And the idea came to him to throw the cow's hide down into the middle of them. On seeing the horns and the black skin (the cow was black, you see), they thought it was the Devil himself who had come looking for them. And so they scarpered in all directions, leaving all their money behind.

"Well, my trick seems to have worked!" said the miller. And he got down out of the tree, gathered up all the money in the cowskin and ran back to the house! He and his wife spent all day counting the money, but even they were unable to come to a final figure, as there was too much money!

The following morning the miller told his wife to go to the seigneur's house and ask to borrow the large scales so they could weigh the money. His wife went off and asked for the scales. 
"What do you need the scales for?" the seigneur asked her.

"To weigh all our money, sir."

“To weigh all your money?! I think you're pulling my leg."

"Oh, my Lord, no sir. I'm telling you the truth. Come with me and I'll show you."

The seigneur went with her. When he saw the miller's table covered in gold coins, he was astounded and said to him, "Where did you get that money from?"

"I got it from the sale of my cowskin in Guingamp, sir."

"From your cowskin?! Cowskins must be fetching a good price then!"

"Yes, sir, they certainly are, and you did me a great favour by killing my cow,"

And the seigneur ran straight back home and killed all of his cows and skinned them. The following morning he sent his servant into town with the skins (he was given the use of a horse) and told him to ask for a pile of money for each one. The servant went off to town with the skins.

"How much for each skin?" a tanner asked him.

"A pile of money!"

“Come on! Don't mess me around, how much for each skin?"

"I've told you, a pile of money."

And when he gave the same answer to everyone the tanners became angry and gave him a thrashing, knocked him to the ground and even stole the skins from 
him. When he arrived back at the house, the seigneur asked him, "Where is the money?"

"Ah, the money! To tell the truth all I got was a good kicking and a beating and my poor body is black and blue."

“The miller has tricked me!" the seigneur cried out in a rage. "But not to worry, I'll get my own back!"

The miller laid on a small feast with the cow that had been killed and he told his wife to go and invite the seigneur as well. The miller's wife went off and delivered the invitation.

"How dare you come to make fun of me again and in my own house?!"

"Jesus! Me, sir, make fun of you? Neither me nor my husband would ever dare to do a thing like that."

"Well then, I'll come anyway and I'll speak to the miller. Perhaps he thinks that he's cleverer than me?"

The seigneur went to eat at the mill. There was loads of grub - pork fat, a spit roast, cider and wine too! Towards the end of the meal, when things had got properly warmed up, the miller said to the seigneur, "Everybody, sir, knows that you are very clever, but all the same I would like to wager that you cannot do what I can do."

"And what is that then?"

"Kill my wife in front of everybody and then bring her back to life by playing this violin here."

"I'll bet twenty crowns that you can't do that." 
“Twenty crowns that I can!"

“Come on then, let's see!" everyone shouted, seeing that the seigneur had accepted the bet.

And the miller took his knife, jumped on his wife and pretended to cut her throat. But he was only cutting a blood-filled bladder that he had placed around her neck. The seigneur, who was unaware of the trick, like everyone else, was horrified to see the blood flowing. The woman fell to the ground as if she were quite dead. The miller then took his violin and started to play. And straight away his wife began to get up and dance, like a madwoman. The seigneur could only stand there and watch her, his mouth open.

"Give me your violin," he said to the miller, "and I'll let you have the mill rent-free for two years."

The deal was done and the seigneur ran back to the house, carrying his violin and very happy. "My wife is getting a little old," he said to himself as he went along. "If only I could make her young again...!"

When he got home, he found his wife in bed, fast asleep! "That's good," he said. "This way she won't know a thing."

He took a knife from the kitchen and cut his wife's throat. And then he started to play his violin! But although he played beautifully, the poor woman neither danced nor budged an inch. She was as dead as could be!

"What a fool that miller is!" he said to himself. "I killed my wife and I played the violin beautifully, but still she's not restored to life! He must have forgotten to tell me something. I'll go and see him quickly." 
He ran to the mill. When he got there he saw the miller in his shirt sleeves, holding a whisk and stirring a large cooking pot which stood in the middle of the yard and inside which the water was boiling. (He had just that minute cleared away the fire from underneath.) He stood watching the miller, his mouth open, and he forgot all about his wife.

"What is that you're doing, miller?"

"I'm boiling the stock, sir, Quickly, come and have a look at it bubbling away." The seigneur stepped forward to look inside the pot and said, "Why, so it is. And you're using your whisk to make it boil like that?"

"Of course, sir. Wood is very expensive and it would be too pricey for me."

“That's true enough. Give me your whisk and I'll let you have the mill rent-free for another two years."

"Seeing as it's you, sir, here you are!" And the seigneur returned home with the whisk and as he arrived, he said to himself, "Now I'm going to chop down all the trees on my land and I'll get lots of money." And he sold all the wood on his land.

One Saturday evening, the cook said to him, “Sir, I haven't any wood left, or even any faggots, so how am I supposed to cook the dinner?"

"I know exactly what to do, cook. Don't you worry about it."

The following morning, which was Sunday, the seigneur said to his staff, his valets and servants, to go of to High Mass, with the exception of Little John, his head valet, who would stay back at the house with him.

"And who's going to get the dinner ready?" asked the cook.

“Don't worry about it and off you go, like I told you." 
So they all went of to the town. Then the seigneur told Little John to carry the large cooking pot into the middle of the courtyard and to fill it with water. Then he added the fat, the salt beef, the cabbage, the turnips, salt and pepper - finally there was everything he needed to make a good stock. Then he took off his jacket, took the miller's whisk and began to stir the pot. But no matter how hard he whisked, the water remained cold.

“What are you doing, Sir?” asked Little John, astonished.

"Shut up, you fool, you'll see soon enough."

And so he continued to stir as best he could. From time to time he dipped his finger into the pot, but the water was always cold. At last when he had had enough, he stopped and said, "Indeed, I'm afraid the miller has been making a fool of me."

"Yes, he's certainly made a fool of you, Sir," replied Little John.

"Ah well, no matter. He will pay for this with his life."

"I think a good beating with the whisk would be sufficient, Sir."

"No, no, Death! Making a fool of me! Come on, quickly, off to the mill! And bring a sack so we can put him in it and throw it into the pond to drown him."

Little John slung an empty sack over his shoulder and they both went off to the mill. The poor miller was bundled into the sack, then loaded onto his own horse to be taken down to the pond which was some distance away. On the way they saw coming towards them on the road a merchant on his way to the fair at Guingamp with three horses all loaded up with goods. The seigneur was frightened. 
"Let's go and hide on the other side of the ditch," he said, "until the merchant has gone by." So they crossed over the ditch into the field. The miller, in his sack, was dumped into the ditch by the side of the road. When he heard the sound of the merchant's horses as the passed by, he cried out, “I won't have her! I won't have her!"

The merchant, astonished, went up to the sack. "Hang on!" he said, "What was that?"

The miller carried on shouting, “No, I won't have her! I won't have her!”

"Whom won't you have?" asked the merchant.

"The only daughter of a very rich seigneur, who has a child already and whose father wants me to marry her."

"And is she really very rich?"

"Yes, richer than anyone in the whole land."

"Well, then I'd be happy to have her."

"Well, quickly then. You get inside the sack and I'll get out."

The merchant got into the sack and the miller secured him inside, then took his whip and went off towards Guingamp with the three horses, fully laden with goods. After he had gone the seigneur and Little John returned for their sack.

"I'll have her! I'll have her!" cried the merchant from inside.

"Whom will you have?" asked the seigneur.

"Your daughter, Sir." 
"Ah, son of a b... go and look for her then in the bottom of the pond!" And they threw him into the pond and he was never seen again.

The following day the seigneur and Little John, his valet, went to the fair at Guingamp. As they walked around all the beautiful stalls that were there, they were completely astounded to find the miller there too, in charge of a beautiful stall selling silverware.

"How is it that you're here, miller?" the seigneur said to him.

"Now surely, Sir, you're going to buy something from me?"

"What? Shouldn't you still be in the pond?"

“As you can see, Sir, I'm not there any more and, moreover, I must thank you because that is where I found all the beautiful things that you see here."

"Really?"

“Just as I said, Sir. My only regret is that you didn't throw me a bit further in. Then I would have landed amongst all the gold items."

"Really?"

"As true as my word, Sir."

"And it's all still there?"

"As far as I know. But you should hurry if you want to go and have a look." 
And the seigneur went back home with his servant and ran to the pond. The seigneur threw Little John into the water and, as he was very large and couldn't swim, he raised his hand out of the water to ask for help.

"Hang on!" said the seigneur. "He's signalling to me with his hand to jump in a bit further. Obviously he's not far enough in for the gold." And he took a run up and jumped in as far as he could.

And not a word has been heard of them ever since.

And that is the story of the Miller and the Seigneur.

(Told by Barba Tassel in the town of Plouaret, December 1868.) 